\title{
The Impact of Climate Change Induced Extreme Events on Agriculture and Food Security: A Review on Nigeria
}

\author{
Oludare Sunday Durodola ${ }^{1,2}$ \\ ${ }^{1}$ Faculty of Technology, Pan African University Institute of Water and Energy Sciences (Including Climate Change), \\ Abou Bekr Belkaid University of Tlemcen, Tlemcen, Algeria \\ ${ }^{2}$ Faculty of Engineering and Technology, Ladoke Akintola University of Technology, Ogbomoso, Nigeria \\ Email: durodolaoludare@gmail.com
}

How to cite this paper: Durodola, O.S. (2019) The Impact of Climate Change Induced Extreme Events on Agriculture and Food Security: A Review on Nigeria. Agricultural Sciences, 10, 487-498. https://doi.org/10.4236/as.2019.104038

Received: March 4, 2019

Accepted: April 8, 2019

Published: April 11, 2019

Copyright ( 2019 by author(s) and Scientific Research Publishing Inc. This work is licensed under the Creative Commons Attribution International License (CC BY 4.0).

http://creativecommons.org/licenses/by/4.0/

\section{cc) (i) Open Access}

\begin{abstract}
The study of the climate change and the effects of climate change induced extreme events on food security are fundamental for the sustainable development of agriculture globally. Climatic factors are the primary important factors affecting agricultural production. Furthermore, the world is now experiencing more frequent and intense droughts and floods in many agricultural regions which damage and at times destroy crops. The effects of climatic change on agriculture have triggered significant trend of research during the last decade globally in order to unfold the solutions to climate change induced extreme events on agriculture. Several studies have been conducted on effects of extreme events such as droughts and flooding induced by climate change on agriculture and food security. These effects include changes in crop and livestock yields as well as the economic consequences of these potential yield changes globally. Therefore, this study reviews the effects of extreme events, including floods and drought, caused by climate change on agriculture and food security with focus on Nigeria in particular. For the study, literatures were identified for review through a comprehensive search by using electronic and non-electronic databases to identify researches conducted on effects on climate change and extreme events on agricultural productivity. From the review, it shows that extreme events such as droughts and floods impact agriculture and food security. In order to mitigate the effects of climate change especially droughts and floods, on agricultural productivity, there is an urgent need to intensity efforts and researches on climate change to mitigate and adapt to the occurrences of these extreme events when necessary in Nigeria. Several mitigation and adaptation measures need to be implemented to mitigate the effects of extreme events on agricultural productivity and food security. These measures include practicing climate-smart
\end{abstract}


agriculture, construction and improvement of drainage networks to effectively dispose of flood water in order to reduce the risks of flooding in urban agriculture and drought-resistant varieties of crops should be cultivated.

\section{Keywords}

Agriculture, Climate Change, Drought, Food Security, Flood

\section{Introduction}

Climate is an important factor affecting agricultural productivity. Agriculture and food production depend fundamentally on climatic factors. Climate refers to the average weather conditions over time while climate change is the long-term change in climate, including average temperature and precipitation [1]. Climate change and global warming resulting from human activities such as increase in the concentration of Greenhouse Gases (GHGs) in the atmosphere are two closely connected phenomena facing humanity in the 21 st century. Climate change is already affecting the earth's temperature, precipitation, and hydrological cycles. Continued changes in the frequency and intensity of precipitation, heat waves, and other extreme events are affecting agricultural production. Climatic changes due to anthropogenic factors have shown that the globe is warming [2] [3].

According to [4] and [5] developing countries, African countries exclusively, have been termed to be at danger as the tropical regions stand to experience some of the most serious effects of climate change. Climate change induced extreme events include floods and droughts. Agriculture, which takes an important part of employment and food provision in Africa, is highly susceptible to climate change. Climate change has already caused a negative impact on agriculture in many parts of the world because of increasingly severe weather patterns [6] [7]. Meanwhile, [8] reported that the major negative effect of climate change is as a result of the increase in temperature which is largely more than the changes in precipitation as simulated by climate models. According to [9] five main climate change related drivers will affect the agriculture sector in ways that will vary in intensity and importance across the regions. They are: temperature rise; precipitation patterns, including rainfall and snow; the incidence of extreme events including floods and droughts; sea-level rise; and the atmospheric carbon dioxide content. This is the main reason why the effects of extreme events such as floods and droughts caused by climate change should be examined especially on agricultural production and food security. For this study, literatures were identified for review through a comprehensive search by using electronic and non-electronic databases to identify researches conducted on effects on climate change and extreme events on agricultural productivity. Keywords such as climate change, agricultural productivity, food security, droughts, floods, Nigeria were used for 
the search.

Climate change and food security are related because climate change affects the climatic conditions responsible for optimum food production. However, research shows climate change will not equally affect all countries, and will likely have the biggest impact in equatorial regions such as sub-Saharan Africa due to its geographical location [10] [11]. This means that countries already struggling with food security are likely to struggle harder in the future if urgent actions and measures are not taken to mitigate climate change and adapt to climate-smart agriculture. Also, [7] affirms that food production will reduce largely due to current and future trend of climate change in Mali and in other Sub-Saharan African countries. However, small scale farmers will suffer more than their large scale counterparts unless early planting and recommended rates of fertilizers are applied in order to achieve food sufficiency in those areas. Climate change is expected to continue to cause floods, worsen desertification and disrupt growing seasons [4]. The Food and Agriculture Organization [1] [12] warns that an increase in average global temperatures of just two to four degrees Celsius above pre-industrial levels could reduce crop yields by 15 - 35 percent in Africa and western Asia, and by 25 - 35 percent in the Middle East. In their separate studies [13] [14] [15] stated that the yield of cereal by 2050 which is the most staple food of West African will reduce by $10 \%$ as a result of climate change. Climate change has become a universal concern and thus becoming a threat to achieving sustainable development of agriculture in Nigeria [10] [11].

Due to the fundamental role of agriculture in human welfare, studies conducted by researchers have revealed the potential effects of climate change especially extreme events on agricultural productivity [4] [7] [12]. Climate change is expected to affect agricultural and livestock production, hydrologic balances, input supplies and other components of agricultural systems [16]. This is in accordance with the report of [7] in Mali, Sub-Sahara Africa. It was reported that future climate change will have extensive influence on small-scale farmers especially those that largely depend on agriculture as their source of income for survival. This is totally against the observation of [15] that climate change will have least impact on small scale farmers in the region. In contrast [17] in a comprehensive study used process-based modeling to evaluate the impact of climate change on crop yields and adaptation options in the Niger River Basin, West Africa discovered that climate change would be two-sided as it was projected to have some positive and negative impacts on food production in the study area. According to the simulated results achieved, it shows that climate change will positively affect the production of maize and sorghum to about $2 \%$ - $6 \%$ increase in the Southern Guinea savanna zone. In the other hand, in the Northern Guinea savanna, production is projected to have $2 \%-20 \%$ decrease due to climate change [17]. These results and studies shows that more studies need to be carried out in order to unfold the impacts of climate change on food security in various locations in Africa and most importantly on individual crop. 


\section{Floods and Droughts Induced by Climate Change}

Flood and drought are caused by several factors ranging from natural occurrences to climate change. In the same vein, flood is also caused by improper waste disposal and generally poor waste management especially solid wastes. Therefore, there is need to distinguish among these causes without erroneously attributing all extreme events to climate change. According to [4] drought is a condition of wide but short-term climatic variation, which results in inadequate rainfall to meet the socio-economic demands of an area in terms of water supply for domestic and industrial uses, agriculture and ecosystem. One of the earliest and most influential interpretations of the cause of drought in the Sahel was that reported by [18], which suggested that reductions in rainfall were the result of human activity. Drought in Sahel region is often attributed to a southward displacement of the Inter Tropical Convergence Zone (ITCZ), but this explanation has been rejected because it failed to explain many important characteristics of rainfall such as late onset or early stoppage [19] [20]. Similar studies have been carried out by [21] [22] that have similarly used long-term data from a number of synoptic stations in Nigeria also yielded some very useful information on the recurrence, persistence and periodicity of severe droughts in Nigeria. Therefore, there is urgent need to evaluate droughts caused as a result of climate change.

According to [23] flood is a general condition of partial or complete inundation of normally dry areas from overflow of inland or tidal waters or from unusual and rapid accumulation of runoff. Floods as noted by [24] are the most frequent disaster and widespread natural hazards of the world. In another report, [25] noted that, floods have caused $84 \%$ disaster deaths in the world with an average of 20,000 deaths per year, which makes only a few countries immune to floods. Consequently, Nigerian flood damage records show that many people have lost their lives to flooding while hundreds of thousands have been rendered homeless and properties worth billions of Naira have been destroyed as a result of devastating floods across Nigeria [12] [26]. A state of food insecurity would occur once any of the food security dimensions is truncated by extreme events such as flooding, drought or any environmental change; hence, there exist a relationship between flooding and food (in) security. In a similar study, [27] [28] found flooding to have significant negative impacts on food security in India and Niger Republic respectively. Consequently, it is necessary to study the implications of climate change induced extreme events in order to adapt to climate change thereby ensuring food security for the general populace.

Evidences from previous researches and past findings have showed that the recent climate change has affected agricultural productivity leading to drastic reduction in the global food production and availability [29] [30] [31]. Climate change is stimulating adverse extreme events like drought and flooding that is causing food shortage and food insecurity in many countries like Somalia, Sudan and other countries that are within the borders of the arid zones [4] [32]. Therefore, it is imperative that extreme events such as floods and droughts will 
continue to affect agriculture and food production especially African countries if appropriate measure are not taken according to [32] in Figure 1.

\section{Climate Change and Effects of Extreme Events on Agriculture: Case Study of Research Examples in Nigeria}

In an extensive study by [12] on the probable effects of climate change on food and crop production in Nigeria concluded that for the remaining years of the $21^{\text {st }}$ century, Nigeria generally will experience low crop yields as a result of intermittent droughts within the country. Some other studies have equally been carried out to determine the effects of climate change on the production of some major food crops in some parts of Nigeria. These include [33] that evaluated the effects of climate change on rice farming in South East, Nigeria. It was reported that climate change will reduce the yield of rice production in the area both in short and long run using econometric tools such as Augmented Dickey Fuller (ADF) test, Johansen Test and Vector Error Correction (VEC) Estimates for the data collected from Nigerian Meteorological Agency and FAOSTAT (Food and Agriculture Organization Statistics). Similarly, [34] examined the impact of climate change on cocoa production in Nigeria which shows that cocoa production will be affected with extreme events such as droughts and floods. For the study, the authors collected data from the relevant agencies. Also, rainfall data for thirty years (1981-2010) were collected from the Nigeria Meteorological Agency to generate seasonality index and reliability index [34]. The data were analyzed using descriptive statistics and correlation analysis and revealed that there is a strong relationship between climate change and decline in agricultural production. In another study [35] considered the effect of climate change on cassava production in Ondo State, Nigeria which reported that there will low yield production of cassava due to climate change. In addition, several studies have been conducted in Nigeria to verify the effects of climate change induced extreme events such as drought and floods on food security and agricultural production. Some are [36] [37] [38] with similar results that extreme events caused by climate change have extensively damaging effects on food production thereby

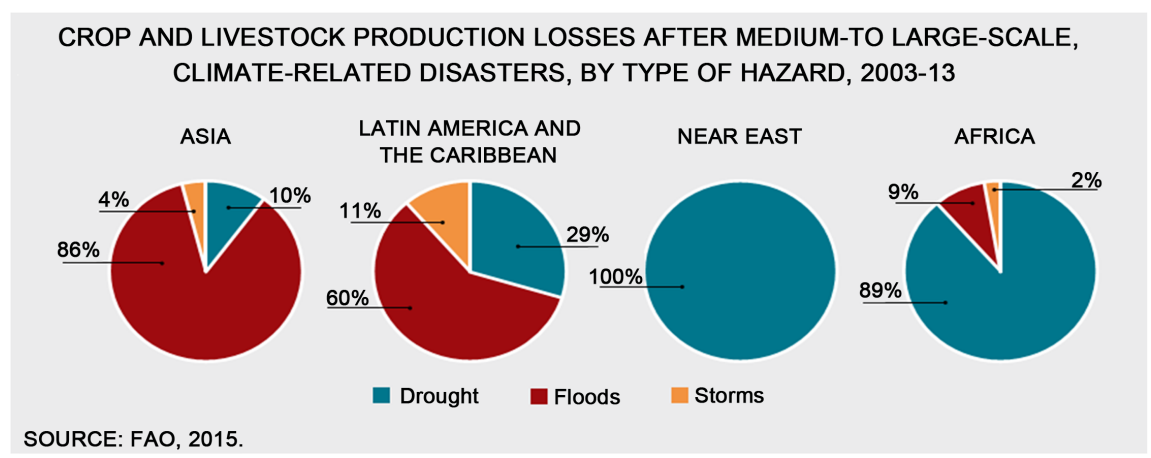

Figure 1. Crop and livestock production losses after medium-to large-scale, climate related disasters by droughts, floods and storms, 2003-2013 (Source: [32]). 
causing low crop yields and food shortages in those in the areas examined. It is imperative to state that all these studies attributed low yields and stumpy food production to extreme events such as droughts and floods as a result of climate change.

[39] observed that Nigerian agriculture depends highly on climate because temperature, sunlight, water, relative humidity are the main drivers of crop growth and yield. Climate can affect the quantities and types of food produced as well as production-related income. Similarly, [11] opined that the climate change phenomenon will affect agriculture in a number of ways including changes in rainfall pattern. It should be noted that there are more uncertainties in the prediction of the beginning of rainy season for farmers. Farmers can no longer predict the commencement of rainy season due to changes in rainfall characteristics. Excess rainfall for crops causes flooding thereby devastating farmlands and eventually leading to crop failure and food shortages. [40] opined that there is desert encroachment and extreme droughts in the northern states as well as serious problems of flooding and erosion in the littoral southern states which are capable of causing food shortages. This calls for more intensive studies in these areas to ascertain these claims through models and simulations. Increasing climate uncertainties, sheet erosion, gully erosion, periodic flooding, biodiversity depletion, agricultural land degradation and general decline in yields of agricultural produce are now common norms in the country as reported by Ibrahim [39].

In a study [41] concluded that changing rainfall pattern in Enugu State, Nigeria could devastate the rain-fed agriculture on which Enugu farmers depend on for survival. Water supplies may also be altered, primarily through changes in temperature and rainfall. In general, climate changes have the potential to lead to large disruptions in agricultural sector in the state and have adverse impacts on food security [41]. According to [42], Climate variability and change have a straight and repeatedly inverse influence on the quantity and quality of agricultural production. [11] stated that Nigeria is not left out of effects of climate change especially with the flooding in the country in 2013 when several hundred of thousands of farmland/crops were being destroyed. The flooding in 2013 was also noted to have caused massive destruction of farmlands which resulted to food insecurity in parts of the country as significant proportion of areas (including the south eastern region) that produce the three main tuber food crops in Nigeria (namely yam, cassava and sweet potato), were affected by the floods [43].

A number of the identified negative effects of flooding on food security are indirect, for instance, roads are important in the transportation of agricultural products from farms to market and when these roads are destroyed by flooding, food security is affected indirectly which is in line with the findings of [44] [45] [46]. In the same vein, when crop failure occurs as a result of flooding, food availability is affected with an associated reduction in meal frequency and quan- 
tities. Flooding was found to reduce crop/fish pond harvest and farm income, thereby affecting household food security in Nigeria especially as majority of the households are dependent on agriculture for their food and income [41] [47]. This agrees with the findings of [48] where $66 \%$ of their respondents strongly agreed that flooding caused loss of fish stock in their ponds. In addition, this is somewhat related to the findings of [49] who noted that flooding caused loss of farm crops in Gwagwalada Area Council in Nigeria, thereby indirectly affecting food security of households. Similarly, food prices are usually low during harvest periods, but flooding alters this seasonal pattern by causing a rise in food prices as a result of crop failure, corroborating the findings of [48] flood events occur mostly between July and October, the harvest season for staples like yam in south eastern Nigeria in the study by [50] show that flooding has negative effects on food security in various aspects.

[11] recommended that measures and actions that can assist to alleviate the adverse effects of drought include drip irrigation, drought resistant crops varieties among others should be put in place by the government. Farmers should equally be sensitized and equipped with skills of adaptation and mitigation of the effects of climate change as this will go a long way to improve large scale food production and urban agriculture in Nigeria. In the same vein, [15] suggested that in order to recognize the most susceptible areas and locations to climate change, the identification of crop varieties that are capable of withstanding the effects of climate change is urgently required. Also, there is need for immediate review of the main effects of climate change on food security to avoid exaggeration and confusion on the impacts of climate change and climate change induced extreme events with other causes. The future of agricultural production relies on both designing new ways to adapt to the impacts of climate change. Climate-smart agricultural practices must be implemented to ensure that agricultural productions are not affected by the occurrence of extreme events.

\section{Recommendations}

From the review, the following recommendations are made:

1) Adaptation strategies for short and long-term changes to human activities that respond to the effects of changes in climate should be put in place. In agriculture, adaptation strategies include well-designed water infrastructure, emergency preparation for and response to extreme weather events, development of resilient crop varieties that tolerate temperature and precipitation stresses, and new or improved land use and management practices.

2) Improved water management in high-emitting, irrigated rice systems through mid-season drainage or alternate wetting and drying has been shown to substantially reduce $\mathrm{CH} 4$ emissions in Asia; this can be implemented in Africa and Nigeria.

3) Construction and improvement of drainage networks to effectively dispose flood water will go a long way in reducing the risks of flooding. Indiscriminate 
dumping of wastes in drainage and water channels prevents the disposal of flood water thereby leading to flooding of farmlands.

4) Drought is difficult to forecast, however, its impacts can be significantly mitigated. This can be achieved through a more proactive, risk-based management approach.

5) The characterization of the possible effects of climate change on crop yields and production, as well as the corresponding impacts on food security, requires computer modelling applications. More researches needs to be conducted in these areas.

6) Implementation of climate-resilient water management and control actions to minimize the risks from extreme events such as droughts and floods should be encouraged among farmers globally.

7) Advance dissemination of information on climate smart agriculture and adaptation planning to farmers.

8) Imperatively, there is urgent need to conduct more research on the effects of climate change induced extreme events on agriculture and food security thereby distinguishing between the these from other causes of extreme events. This is due to the fact that climate change is not the only cause of extreme events.

\section{Conclusion}

Climate change will continue to have significant effects on agriculture and food security over the next few decades and beyond. This implies that extreme events especially droughts and floods as a result of climate change, will negatively affect food production and output in Nigeria in both short and long run. Hence, there is an urgent need for actions to minimize or ameliorate flood hazards. Flood protection through engineering and structures such as embankment, dikes, levees, river channelization and flood diversion channels should be constructed by the government to alleviate the adverse effects of floods on farmlands. Institutional capacity should be strengthened to meet up the international requirements on climate change. In addition, farmers should equally be sensitized and trained on climate-smart agriculture in order to adapt and mitigate the effects of climate change on agricultural production and food security. Finally, more intensive and elaborate studies need to be done globally to unfold the effects on climate change on agriculture and food security. There is a need for more modeling and simulation projections on the impacts of climate change to be done on various crops cultivation with respect to different locations. More research is needed to distinguish among extreme events induced by climate change, those extreme events caused by natural occurrences and those that are man-made as consequences of improper waste management and other causes.

\section{Conflicts of Interest}

The author declares no conflicts of interest regarding the publication of this paper. 


\section{References}

[1] FAO (2008) Expert Meeting on Global Perspectives on Fuel and Food Security. Technical Report, Rome.

[2] Odingo, R.S. (2008) Climate Change and Economic Development, Issues, Challenges and Opportunities for Africa in the Decades Ahead. University of Nairobi, Nairobi.

[3] IPCC (2007) Climate Change 2007: The Physical Science Basis: Summary for Policymakers. IPCC Secretariat, Geneva, 21.

[4] Idowu, O.O. and Francois, I.M. (2017) American Journal of Applied Sciences, 14 930-937. https://doi.org/10.3844/ajassp.2017.930.937

[5] Akumaga, U. and Tarhule, A. (2018) Projected Changes in Intra-Season Rainfall Characteristics in the Niger River Basin, West Africa. Atmosphere, 9, 497. https://doi.org/10.3390/atmos9120497

[6] IPCC 2014 Climate Change 2014. Impacts, Adaptation, and Vulnerability. Working Group II, Cambridge University Press, Cambridge, UK.

[7] Traore, B., Decheemaeker, K., Van Wijk, M.T., Corbeels, M., Supit, I. and Giller, K.E. (2017) Modelling Cereal Crops to Assess Future Climate Risk for Family Food Self-Sufficiency in Southern Mali. Field Crops Research, 201, 133-145. https://doi.org/10.1016/j.fcr.2016.11.002

[8] Roudier, P., Sultan, B., Quirion, P. and Berg, A. (2011) The Impact of Future Climate Change on West African Crop Yields: What Does the Recent Literature Say? Global Environmental Change, 21, 1073-1083.

https://doi.org/10.1016/j.gloenvcha.2011.04.007

[9] FAO (2011) Climate Change, Water and Food Security. FAO Water Reports, Rome.

[10] Ellis, S. (2008) The Changing Climate for Food and Agriculture: A Literature Review. Institute for Agriculture and Trade Policy, Minneapolis, Minnesota.

[11] Felix, O., Mangodo, C., Ighodaro, U.B. and Owombo, P.T. (2016) Climate Change and Food Production in Nigeria: Implication for Food Security in Nigeria. Journal of Agricultural Science, 8, 74-83. https://doi.org/10.5539/jas.v8n2p74

[12] Adejuwon, J.O. (2006) Food Crop Production in Nigeria II. Potentials Effects of Climate Change. Climate Research, 32, 229-245. https://doi.org/10.3354/cr032229

[13] Schlenker, W. and Lobell, D.B. (2010) Robust Negative Impacts of Climate Change on African Agriculture. Environmental Research Letters, 5, Article ID: 014010. https://doi.org/10.1088/1748-9326/5/1/014010

[14] Rosenzweig, C., Elliott, J., Deryng, D., Ruane, A.C., Muller, C., Arneth, A., Boote, K.J., Folberth, C., Glotter, M., Khabarov, N., et al. (2013) Assessing Agricultural Risks of Climate Change in the 21st Century in a Global Gridded Crop Model Intercomparison. Proceedings of the National Academy of Sciences of the United States of America, 111, 3268-3273. https://doi.org/10.1073/pnas.1222463110

[15] Sultan, B., Guan, K., Kouressy, M., Biasutti, M., Piani, C., Hammer, G.L., McLean, G. and Lobell, D.B. (2014) Robust Features of Future Climate Change Impacts on Sorghum Yields in West Africa. Environmental Research Letters, 9, Article ID: 104006. https://doi.org/10.1088/1748-9326/9/10/104006

[16] Aydinalp, C. and Cresser, M.S. (2008) The Effects of Global Climate Change on Agriculture. American-Eurasian Journal of Agricultural \& Environmental Sciences, 3, 672-676.

[17] Akumaga, U., Tarhule, A., Piani, C., Traore, B. and Yusuf, A.A. (2018) Utilizing 
Process-Based Modeling to Assess the Impact of Climate Change on Crop Yields and Adaptation Options in the Niger River Basin, West Africa. Agronomy, 8, 11. https://doi.org/10.3390/agronomy8020011

[18] Charney, J., Quirk, W.J., Chow, S.H. and Kornfield, J. (1977) A Comparative Study of the Effects of Albedo Change on Drought in Semi-Arid Regions. Journal of the Atmospheric Sciences, 34, 1366-1385. https://doi.org/10.1175/1520-0469(1977)034<1366:ACSOTE >2.0.CO;2

[19] Nicholson, S.E. and Tucker, C.J. (1998) Desertification, Drought and Surface Vegetation: An Example from the West African Sahel. Bulletin of the American Meteorological Society, 79, 815-829.

[20] Nicholson, S.E. (1993) An Overview of African Rainfall Fluctuation of the Last Decade. Journal of Climate, 6, 1463-1466. https://doi.org/10.1175/1520-0442(1993)006<1463:AOOARF >2.0.CO;2

[21] Adefolalu, D.O. (2007) Climate Change and Economic Sustainability in Nigeria. Proceedings of the International Conference on Climate Change and Economic Sustainability, Nnamdi Azikiwe University, Awka, 12-14 June 2007, 36-49.

[22] Tarhule, A. and Woo, M. (1998) Changes in Rainfall Characteristics of Northern Nigeria. International Journal of Climatology, 18, 1261-1271. https://doi.org/10.1002/(SICI)1097-0088(199809)18:11<1261::AID-JOC302>3.0.CO; $\underline{2-Z}$

[23] Jeb, D.N. and Aggarwal, S.P. (2008) Flood Inundation Hazard Modelling of the River Kaduna Using Remote Sensing and Geographic Information Systems. Journal of Applied Sciences Research, 4, 1822-1833.

[24] Odufuwa, B.O., Adedeji, O.H. and Oladesu, J.O. (2012) Floods of Fury in Nigerian Cities. Journal of Sustainable Development, 5, 69-79. https://doi.org/10.5539/jsd.v5n7p69

[25] UN-Water (2011) Cities Coping with Water Uncertainties. Media Brief, UN Water Decade Programme on Advocacy and Communication.

[26] Olorunfemi, F.B. (2011) Managing Flood Disasters under A Changing Climate: Lessons from Nigeria and South Africa. NISER Research Seminar Series, Ibadan.

[27] Ramakrishna, G., Gaddam, S.R. and Daisy, I. (2014) Impact of Floods on Food Security and Livelihoods of IDP Tribal Households: The Case of Khammam Region of India. International Journal of Development and Economics Sustainability, 2, 11-24.

[28] Zakari, S., Ying, L. and Song, B. (2014) Factors Influencing Household Food Security in West Africa: The Case of Southern Niger. Sustainability, 6, 1191-1202. https://doi.org/10.3390/su6031191

[29] Kurukulasuriya, P. and Mendelsohn, R. (2006) Crop Selection: Adapting to Climate Change in Africa. CEEPA Discussion Paper No. 26, Centre for Environmental Economics and Policy in Africa, Pretoria, South Africa.

[30] IISD (International Institute for Sustainable Development) (2007) Community Based Adaptation to Climate Change Bulletin. A Summary of the Second International Workshop on Community-Based Adaptation to Climate Change. IISD Reporting Services.

[31] Lobell, D.B., Burke, M.B., Tebaldi, C., Mastrandrea, M.D., Falcon, W.P. and Naylor, R.L. (2008) Prioritizing Climate Change Adaptation Needs for Food Security in 2030. Science, 319, 607-610. https://doi.org/10.1126/science.1152339

[32] FAO (2015) The State of Food and Agriculture; Climate Change, Agriculture and Food Security. Rome. 
[33] Henri-Ukoha, A., Orebiyi, J.S., Eze, C.C., Ibekwe, U.C. and Nwaiwu, L.U. (2014) Analysis of Climate Change and Food Security among Rice Farmers in Abia State, Southeast Nigeria. Proceedings of the Annual National Conference of the Nigerian Association of Agricultural Economists, Nigeria, February 2014, 686-692.

[34] Sanusi, W.A. and Oladejo, J.A. (2014) Impact of Climate Change on Cocoa Production in Nigeria. Proceedings of the Annual National Conference of the Nigerian Association of Agricultural Economists, Nigeria, February 2014, 679-685.

[35] Akinbola, A.E. and Imoudu, P.B. (2014) Effects of Climate Change on Cassava Production in Ondo: A Co-Integration Approach. Proceedings of the Annual National Conference of the Nigerian Association of Agricultural Economists, Nigeria, February 2014, 695-701.

[36] Oyekale, A.S. (2012) Vulnerability of Peasant Cocoa Farmers to Climate Change in South-West Nigeria. Journal of Human Ecology, 40, 33-41. https://doi.org/10.1080/09709274.2012.11906521

[37] Salau, M.A., Babatunde, K.M. and Adekanmbi, O.A. (2015) Climate Change and Its Mitigation on the Rural Cattle Farmers: Lessons from Saki Area of Oyo State, Nigeria. Nigerian Journal of Agricultural Economics, 5, 27-36.

[38] Orebiyi, J.S., Tasie, C.M., Onyemauwa, C.S. and Emeya, S. (2014) Mitigating Climate Change Effects on Agriculture in Nigeria. Proceedings of the Annual National Conference of the Nigerian Association of Agricultural Economists, Nigeria, February 2014, 708-715.

[39] Adejuwon, S.A. (2004) Impact of Climate Variability and Climate Change on Crop Yield in Nigeria, Contributed Paper to Stakeholders Workshop on Assessment of Impact and Adaptation to Climate Change (AIACC), 2-8.

[40] El-Ladan, I.Y. (2014) Climate Change and Food Security in Nigeria, Conference Paper.

[41] Enete, I.C. (2014) Impacts of Climate Change on Agricultural Production in Enugu State, Nigeria. Journal of Earth Science \& Climatic Change, 5, 234.

[42] Sowunmi, F.A. and Akintola, J.O. (2010) Effect of Climatic Variability on Maize Production in Nigeria. Research Journal of Environmental and Earth Sciences, 2, 19-30.

[43] Famine Early Warning Systems Network (FEWSNET) (2013) Nigeria Food Security Update. Food Insecurity Increases in Regions Affected by Flooding and Conflict, FEWSNET, 1-2.

[44] Etuonovbe, A.K. (2011) The Devastating Effect of Flooding in Nigeria. Hydrography and Environment, TS06J, Epworth, Zimbabwe.

[45] Adewuyi, T.O. and Olofin, E.A. (2014) Spatio-Temporal Analysis of Flood Incidence in Nigeria and Its Implication for Land Degradation and Food Security. Journal of Agricultural Science, 6, 150-159. https://doi.org/10.5539/jas.v6n2p150

[46] Duru, P.N. and Chibo, C.N. (2014) Flooding in Imo State Nigeria: The Socio Economic Implication for Sustainable Development. Humanities and Social Sciences Letters, 2, 129-140.

[47] Adejuwon, J.O. (2005) Food Crop Production in Nigeria. I. Present Effects of Climate Variability. Climate Research, 30, 53-60. https://doi.org/10.3354/cr030053

[48] Otomofa, J.O., Okafor, B.N. and Obienusi, E.A. (2015) Evaluation of the Impacts of Flooding On Socio-Economic Activities in Oleh, Isoko South Local Government Area, Delta State. Journal of Environment and Earth Science, 5, 155-171.

[49] Ikani, D.I. (2016) An Impact Assessment of Flooding on Food Security among Ru- 
ral Farmers in Dagiri Community of Gwagwalada Area Council, Abuja. Nigeria, Agricultural Development, 1, 6-13.

[50] Akukwe, T.I., Krhoda, G.O. and Oluoko-Odingo, A.A. (2018) Principal Component Analysis of the Effects of Flooding on Food Security in Agrarian Communities of South Eastern Nigeria. International Journal of Hydrogen, 2, 205-212.

https://doi.org/10.15406/ijh.2018.02.00070 